\title{
A Cause of Rectal Mass: Diffuse Large B-Cell Lymphoma
}

\author{
Bir Rektal Kitle Nedeni: Diffüz Büyük B-Hücreli Lenfoma
}

\author{
Tayfun KAYA ${ }^{1}$ \\ (D) 0000-0001-7101-1952 \\ Semra DEMÍRLI ATICI ${ }^{\mathbf{1}}$ \\ (D) 0000-0002-8287-067X \\ Bülent CALIK ${ }^{1}$ \\ (1) 0000-0002-9054-1446 \\ Gülen GÜL ${ }^{2}$ \\ (10) 0000-0001-5750-0098
}

\begin{abstract}
The most commonly seen pathological type of rectal cancer is adenocarcinoma. The involvement of the colorectal tract with diffuse large B-cell lymphoma is a very rare clinical condition. A-65-year old man was admitted with complaints of weight loss and hematochezia. A rectal mass that mimicked rectal carcinoma was diagnosed by rectal examination and supported by the colonoscopy. The final report of the rectal mass biopsy reported as rectal lymphoma. Thoracoabdominal computed tomography was showed rectal wall thickening which surrounded small lymph nodes. Additional examinations didn't reveal any evidence of infiltration to other organs. The patient diagnosed as primary rectal lymphoma and chemotherapy was started by the hematology department. Rare pathologies such as rectal lymphoma must be kept in mind in the differential diagnosis of rectal mass cases. Since both rectal carcinoma and rectal lymphoma have similar appearances in clinical and radiological studies, it is difficult to make a differential diagnosis.

Keywords: Rectal lymphoma; rectal mass; diffuse large B-cell lymphoma.

öz

Rektum kanserinin en sık görülen patolojik tipi adenokarsinomdur. Diffüz büyük B-hücreli lenfomanın kolorektal sistem tutulumu çok nadir görülen bir klinik durumdur. Atmış beş yaşında erkek hasta kilo kaybı ve hematokezya şikayetleri ile başvurdu. Rektal muayene ile rektal karsinomu taklit eden bir kitle teşhis edildi ve kolonoskopi ile desteklendi. Rektal kitle biyopsisinin nihai raporu rektal lenfoma olarak raporland. Çekilen torakoabdominal bilgisayarlı tomografi rektum çevresinde küçük lenf nodları ve rektum duvarında kalınlık artışı olduğunu gösterdi. Yapılan ek tetkikler başka bir organ tutulumu olmadığını gösterdi. Hasta primer rektum lenfoma tanısı aldı ve hematoloji bölümü tarafindan kemoterapi başlandı. Rektal kitle vakalarının ayırıcı tanısında rektal lenfoma gibi nadir patolojiler akılda tutulmalıdır. Hem rektal karsinom hem de rektal lenfoma klinik ve radyolojik çalışmalarda benzer görünümlere sahip olduğundan, ayırıcı tanı zordur.

Anahtar kelimeler: Rektal lenfoma; rektal kitle; diffüz büyük B-hücreli lenfoma
\end{abstract}

\section{INTRODUCTION}

Primary rectum lymphoma (RL) is a rare tumor that constitutes about $0.2-0.6 \%$ of all colorectal tumors (1). Diffuse large B cell lymphoma (DLBCL) subtype is the most common subtype of colorectal lymphoma (1). RLs are diagnosed in advanced stages due to nonspecific symptoms and clinical presentations that are not specific to the disease. Although surgical resection is often possible in the management of RL, the choice of medical therapy and surgical treatment is still controversial, and optimal treatment has not yet been described. Here, we aimed to present an elderly male patient, diagnosed with DLBCL of the rectum that managed medically, with the

Received / Geliş Tarihi : 10.02.2020 Accepted / Kabul Tarihi : 23.03.2020 Available Online /

Çevrimiçi Yayın Tarihi : 25.04.2020 current light of the literature. 


\section{CASE REPORT}

A 65-year-old male patient without any history of chronic disease or previous operation presented with a complaint of weight loss, anorexia and rectal bleeding for 3 months. The rectal examination of the patient revealed a palpable mass which fixed to the rectal wall. A colonoscopic examination revealed a rectal mass lesion with necrotic tissues covering more than half of the lumen approximately $2-4 \mathrm{~cm}$ proximal from the dentate line. Histopathological sections showed a neoplastic lymphocytic infiltrate of moderate to large size with nucleolar prominence (Figure 1). The cells that make up this infiltrate are positive for CD20 (Figure 2), $\mathrm{Bcl} 2$ and MUM1. Furthermore, most of these cells are Bcl6 positive. These cells were negative with CD5, CD10, cyclin D1, and pan-cytokeratin. Ki67 proliferative index was $40 \%$. The case was reported as DLBCL with morphological and immunohistochemical findings. In thoracoabdominal computed tomography (CT), no pathological findings or other organ involvements were observed except for the increase in thickness in the rectal wall and peripheral lymphadenopathies around the rectum wall. The patient was referred to the hematology department to receive chemotherapy treatment. Written informed consent was obtained from the patient for publication and any accompanying images.

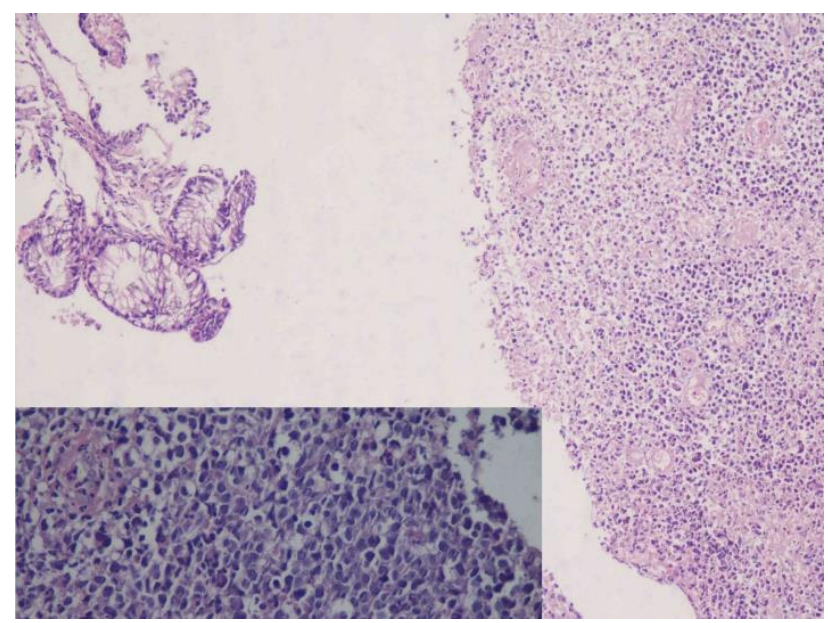

Figure 1. Diffuse neoplastic lymphocytic infiltrate of moderate to large size with nucleolar prominence, hematoxylin eosin, 100x (inlet, 400x)

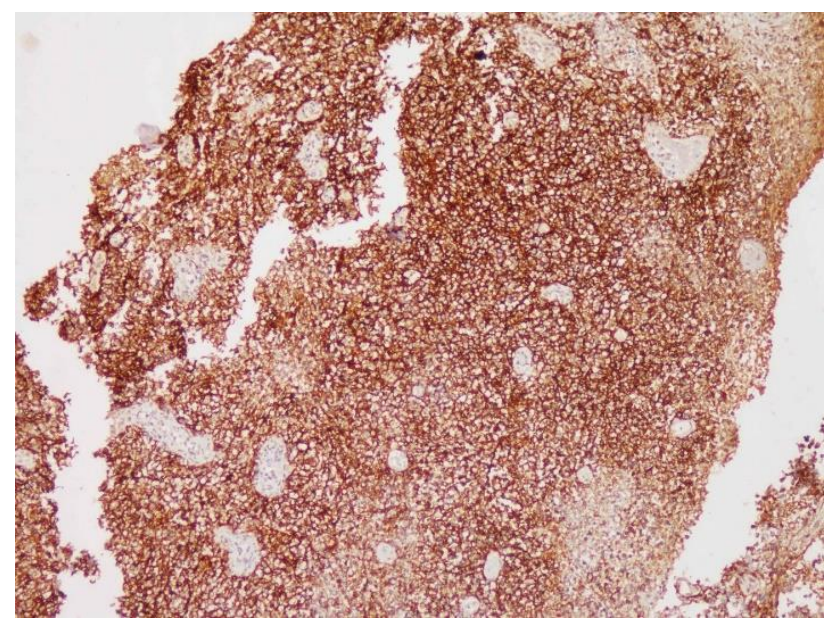

Figure 2. Diffuse CD20 positivity, 100x

\section{DISCUSSION}

Colorectal lymphoma is an extremely rare disease. The incidence of RL is $0.2-0.6 \%$ of all colonic carcinomas and $10-15 \%$ of all primary lymphomas of the gastrointestinal tract $(1,2)$. The most common colon placement of lymphoma is cecum with a rate of $70 \%$, followed by the rectum and ascending colon (2). Although gastrointestinal lymphoma has been correlated with immune deficiency, immunosuppression, and inflammatory bowel disease, our case did not have any chronic disease or history of operation to support it $(1,2)$. The patient had five criteria supporting gastrointestinal lymphoma defined by Dawson et al. (3). No superficial lymph node was detected in the physical examination of him. Although abdominal CT supports the localized lymphadenopathies around the rectum, spleen and liver involvement and mediastinal lymphadenopathy were not seen in the thorax and abdominal CT. No pathological findings were observed about white blood cells in laboratory tests (3). Since both rectal carcinoma and RL have similar appearances in clinical and radiological studies, it is difficult to make a differential diagnosis. However, in this case, CT and histopathological examination guided us to distinguish between RL and rectal carcinoma. Although surgical resection is the basis of treatment in non-metastatic resectable rectal cancer, therapeutic treatment of $\mathrm{RL}$ remains uncertain due to the rarity of it. Although there are studies indicating that radical surgical resection or even local resection is more useful in the treatment of RL, many authors consider medical management to be the primary treatment (4,5). In RL, the correct diagnosis of the disease directly affects the patient's prognosis and the choice of treatment to be administered to the patient. In the treatment of RL, the patient may have a chance to cure without the need for surgery. In conclusion, the fact that RL is very rare and the clinical signs and symptoms are very similar to rectal carcinoma causes a great difficulty in diagnosing of the disease. Differentiation of RL from rectal carcinoma is important because staging, treatment, and prognosis are different from each other. Prospective randomized controlled trials with larger patient series are needed to identify risk factors for the RL and determine the most appropriate treatment method.

\section{REFERENCES}

1. Tevlin R, Larkin JO, Hyland JM, O'Connell PR, Winter DC. Primary colorectal lymphoma - A single centre experience. Surgeon. 2015;13(3):151-5.

2. Vahedian Ardakani J, Rashidian N, Adman AA, Keramati MR. Rectal lymphoma: Report of a rare case and review of literature. Acta Med Iran. 2014;52(10):791-4.

3. Dawson IM, Cornes JS, Morson BC. Primary malignant lymphoid tumors of the intestinal tract. Report of 37 cases with a study of factors influencing prognosis. Br J Surg. 1961;49:80-9.

4. Bilsel Y, Balik E, Yamaner S, Bugra D., Clinical and therapeutic considerations of rectal lymphoma: a case report and literature review. World J Gastroenterol. 2005;11(3):460-1.

5. Maguire LH, Hawkins AT. Surgical resection for primary rectal lymphoma: Support for local excision? J Surg Res. 2019;244:189-95. 